\title{
Human Capital: Demographic Dimensions as Triggers the Survival of Small and Medium Enterprises (SMEs)
}

\author{
Agus D. Sasono ${ }^{1}$, Arief D. Atmoko ${ }^{2}$, Nurul Aini $^{3}$, Elok Damayanti $^{4}$ \\ \{agusdwisasono10@gmail.com , Arif.atmoko@gmail.com², Aininurul349@gmail.com ${ }^{3}$ \} \\ Masters in Management Department, Narotama University, Jl. AR Hakim 51 Surabaya - Indonesia ${ }^{1}$, \\ Law Department, Narotama University, Jl. AR Hakim 51 Surabaya - Indonesia ${ }^{2}$ \\ Accounting Department, Narotama University, Jl. AR Hakim 51 Surabaya - Indonesia ${ }^{3}$
}

\begin{abstract}
The development of the business world is currently changing from the traditional industrial economy to the new economy of knowledge-based resources. Therefore the company is required to restructure its business in order to compete, because it is recognized as a new success lever that has become a Critical Success Factor. In this study using qualitative descriptive combined with confirmatory exploration, with exogenous latent variables Demographics and endogenous Information Technology and Survival. To answer the hypothesis in this study used Structural Equation Modeling, with populations and samples on SMEs in 7 regions of GERBANGKERTASUSILA and the research samples were Regions that have SME environments. The purpose of this study is to analyze the impact of Human Capital seen from the demographic dimensions of the owner and its indicators as a trigger for performance in the form of survival of small and medium-sized SME businesses in order to improve competitiveness and comparability of the aspects of resources owned by small and medium enterprises.
\end{abstract}

Keywords: Human Capital, Demographics, Information Technology, Customer Relations, SMEs

\section{Introduction}

Globalization and changes in information technology are rapidly impacting changes in the structure of traditional industrial economies towards new knowledge-based economies (such as computers and networks) with non-financial measures. In order for companies to be able to compete, survive and win the competition, companies must make strategic and operational changes, namely restructuring in their business, continuously innovating the products they produce, redesigning their business processes, and organizational design to be more efficient[1]. For that companies need to recognize measure and regulate the resources they have, and those resources must have uniqueness or specifications for the company, because of their uniqueness and specifications as a trigger for new success [2].

1explains that a new economy is a knowledge-based economy that has intangible characteristics. Because the nature of knowledge itself is intangible, knowledge and intangible are assumed to be the same for its use, because both are used for the concept of resources or non-physical assets. This similarity is supported by [3],[4], and [5] who explain the term only for different uses. Accounting literature uses the term intangible, management literature, especially human resource management, uses intellectual terms and the economic literature uses knowledge. 
Human Capital is a concept that is used as a collective name for the trigger of a company's new performance [6], as resources that are valued in the scope of knowledge [7], have become Critical Success Factors almost for all types of organizations, and more trusted as a substitute for physical assets to be non-physical, and recognized as a trigger for new success [8]; [9]. Human Capital can be viewed from the aspect of static or resources [4] or stock owned [3].

From the background of the problem and the findings of the researchers as described in the paragraphs above, this study answers the question: How do the direct and indirect effects of the Demographic dimension of Human Capital as a trigger for the survival of small and medium enterprises (SMEs) in an environment of craftsmen to avoid bias due to external factors, besides that it also has a special purpose, namely:

1). Identifying static human capital indicators

2). Develop a human capital interaction model for small and medium enterprises (SMEs).

In an effort to answer the questions and objectives of the research above we use a quantitative approach using Structure Equation Model (SEM).

\section{REVIEW OF THEORY}

\subsection{Human Capital}

Human capital is represented by overall investment, such as education, health, training in the workplace that can increase one's productivity in the labor market and outside the labor market 10. Viewed from a social perspective it is generally defined as the innate abilities, knowledge, and skills that individuals have throughout their lifetime 11 . This innate ability represents the potential received by individuals freely without involving costs, while knowledge and skills are actualization of potential through individual efforts involving costs. Both of these components can increase individual productivity in producing goods, services, and ideas in a business environment. 11 suggested the definition of human capital broadly, among others, can be seen from the specific aspects obtained both formally and informally. Formal acquisition is generally carried out through established institutions and programs, where knowledge and skills are transmitted in the educational environment. Human capital can also be obtained informally, through various social organizations, personal contact, work experience (learning by doing), and self-teaching.

From an individual perspective it only focuses on knowledge and skills and uses economic logic to study individual investments in skills to increase knowledge and productivity 12 . This theory suggests that human capital is individually better quality or better at carrying out relevant tasks, so that human capital is related to the knowledge and abilities of individuals that enable changes in action. Human capital can be developed through formal training and education aimed at renewing and renewing the ability of individuals to run well in society. The most influential concept in this theory is the difference drawn between human capitals in general and specifically12. Human capital generally refers to knowledge and skills that can be applied to various activities, while specific human capital refers to knowledge and skills relevant to a particular context.

By applying human capital theory to SME entrepreneurs, it is hoped that there will be a positive relationship between human capital of SME entrepreneurs (both general and specific) 
and their performance. 13 argue that human capital with entrepreneurial characteristics can increase the productivity of SME entrepreneurs, which results in higher SMEs performance. Higher levels of productivity of SME entrepreneurs mean business owners are more efficient in managing operations or able to attract more customers, negotiate better contracts with suppliers, and increase more capital from investors. From here, it can be said that human capital increases performance and plays an important role in the market selection process.

\subsection{Information Technology}

Technological factors can affect all aspects of a business, from the overall strategic position to how to manage marketing, design, production and distribution 14. The technological factors considered in this study are access to technology and information.

\subsection{Information Technology}

Technology is widely recognized by the strategic management literature 15 , as part of organizations and industries used for the creation of competitive advantage, technology can help maximize business opportunities. According to 16, SMEs need access to the right technology if they have a competitive advantage. The inability to secure technology at start-up can have a negative impact on the process of developing entrepreneurship in today's world of globalization 15. 17 In the study of SMEs in Vietnam found that the lack of equipment and the obsolescence of technology hampered the development of SME development. Whereas 17 found that technological change innovation has a significant relationship with business growth.

Access to new information is very necessary for the initiation, survival and growth of the company 10. 17 The availability of new information is found to depend on personal characteristics such as the level of education, quality of infrastructure such as media coverage and telecommunications systems. Effective and quality use of business information has been identified as very important in helping achieve long-term sustainable growth goals and the success of SME managers, 17 found that there was a positive relationship between the level of information usage and SME performance, shows that the ability of entrepreneurs to access information is an important factor that influences the success of their business.

\subsection{Performance}

Performance is the result of work achieved by a person or group of people in an organization for a certain period of time, in order to achieve the objectives of the organization concerned. Performance in various literatures is referred to as company success, 18 , but the term success of many companies in research is still no agreement about the literature what is meant by the success of the company. Survival is often referred to as the success 19, survival 11, growth 20 and is sometimes used interchangeably.

A large number of studies in the field of entrepreneurship see the concept of success as being the same as survival. 19 argues that the longer the business can survive it is said to be more successful while 11 say survival is a success in its business activities continuously and does not mingle from its business. The decision to stop the operation or continue the business depends on the entrepreneur, and more specifically on his professional and personal interests, because in many cases this decision will have a significant impact on his / her lifestyle. 
The literature on the survival of the company has identified several factors that influence the survival of SMEs. 13 identified and classified survival into three groups of factors: (i) individual specific factors; (Ii) company-specific factors and (iii) environmental factors. The characteristics of individual founders are identified by the theory of human capital as a prerequisite for the survival of SMEs. These characteristics are explained in the literature by researchers from various fields. For example, sociologists tend to identify the founder's socialdemographic attributes; psychologists tend to list personality traits.

There is a strong view in the literature that the success of a business is due to entrepreneurs. Business is created for personal purposes so that the characteristics of entrepreneurs appear to be important. However, 'choosing winners' is often a post-hoc activity and trait theory has received severe criticism. 22 said there was a relationship between success and personality characteristics.

Most studies of company survival find that the age and size of a company seems to positively influence survival (Henderson, 1999). The company's age perspective shows that new companies face greater risk of failure than older companies. This is because older companies will be more established and tends to have more advanced routines and processes and greater access to resources than younger companies 23. However, companies may face a decline in resource support because they are faced with a new environment 21 . While economists base their arguments on the role of adapting to change by emphasizing that the survival of a company depends on success in adapting new ways of doing business.

\section{RESEARCH METHODS}

\subsection{Method}

\subsubsection{Participants}

The population of this study is small and medium enterprises in an environment of craftsmen in 7 regions including Gresik districts, Bangkalan districts, Mojokerto City, Mojokerto districts, Surabaya City, Sidoarjo districts and Lamongan districts, with the aim of minimizing diversity company behavior because of the influence of external environmental factors from the company so that it will have more undirected effects. Besides that, it is because understanding intellectual capital is an example that represents the whole company. The sample units in this study are small and medium enterprises that are in an environment of craftsmen in the 7 regions above which have criteria for small and medium enterprises including the number of workers, sales turnover per year and assets. The determination of the overall sample size is guided by the opinion of 24 that in order to obtain representative data if the population is more than 1000 samples are used at $10 \%-15 \%$.

The sampling technique used in sampling from each population and sub-population in this study is a proportionate random sampling proportional random sampling, which techniques for each sub-population.

The population and selected samples used in this study are shown in Table 1 below.

Table 1: Region, Population and Sample Research

\begin{tabular}{llll}
\hline Region & Population & Sample & $\%$ \\
\hline Gresik Districts & 180 & 26 & $14 \%$
\end{tabular}




\begin{tabular}{llll} 
Bangkalan Districts & 210 & 32 & $15 \%$ \\
Mojokerto City & 256 & 36 & $14 \%$ \\
Mojokerto Districts & 410 & 49 & $12 \%$ \\
Surabaya City & 425 & 55 & $13 \%$ \\
Sidoarjo Districts & 380 & 43 & $11 \%$ \\
Lamongan Districts & 210 & 28 & $13 \%$ \\
\hline
\end{tabular}

Based on Table 1 of the total population of 2350 small and medium enterprises in the environment of craftsmen, the sample samples that were collected were $11 \%$ of the population that was equal to 269 small businesses and medium, using the method proportionate random sampling. The selection of a total sample of 269 small and medium enterprises can be determined by the number of units of analysis in this study as presented in table 2 as follows:

Table 2: Ratio of Research Respondents

\begin{tabular}{|c|c|c|c|c|c|c|c|c|c|}
\hline \multirow{2}{*}{ Participants } & \multirow{2}{*}{ Description } & \multicolumn{7}{|c|}{ Region } & \multirow[t]{2}{*}{$\%$} \\
\hline & & 1 & 2 & 3 & 4 & 5 & 6 & 7 & \\
\hline \multirow[t]{4}{*}{ 1. Age } & $\leq 25$ & 3 & 6 & 2 & 3 & 10 & 8 & 4 & $13 \%$ \\
\hline & $25-45$ & 13 & 14 & 21 & 23 & 25 & 20 & 15 & $48 \%$ \\
\hline & $45-60$ & 5 & 11 & 11 & 20 & 20 & 15 & 8 & $33 \%$ \\
\hline & $\geq 60$ & 5 & 1 & 2 & 3 & 4 & 3 & 1 & $6 \%$ \\
\hline \multirow[t]{4}{*}{ 2.gender } & Male & 19 & 23 & 25 & 37 & 37 & 28 & 20 & $70 \%$ \\
\hline & women & 7 & 9 & 11 & 12 & 18 & 15 & 8 & $30 \%$ \\
\hline & Middle School & 5 & 11 & 7 & 13 & 9 & 8 & 8 & $23 \%$ \\
\hline & Diploma & 4 & 6 & 6 & 15 & 10 & 10 & 6 & $21 \%$ \\
\hline \multirow{5}{*}{ 3.Education } & Bachelor & 7 & 9 & 16 & 15 & 26 & 17 & 9 & $37 \%$ \\
\hline & Master & 5 & 6 & 6 & 6 & 6 & 8 & 6 & $16 \%$ \\
\hline & Doctor & 5 & 0 & 1 & 0 & 0 & 1 & 0 & $44 \%$ \\
\hline & Other & 0 & 0 & 0 & 0 & 0 & 0 & 0 & $0 \%$ \\
\hline & Owner & 3 & 5 & 5 & 11 & 13 & 6 & 11 & $20 \%$ \\
\hline \multirow[t]{2}{*}{ 4. Job } & Manager & 4 & 2 & 3 & 3 & 2 & 2 & 2 & $9 \%$ \\
\hline & Owner and Manager & 19 & 25 & 28 & 35 & 40 & 35 & 15 & $73 \%$ \\
\hline 5.Ownership & Own & 14 & 28 & 25 & 38 & 45 & 38 & 25 & $79 \%$ \\
\hline \multirow[t]{2}{*}{ Status } & Partly Family Owned & 9 & 2 & 2 & 5 & 2 & 3 & 1 & $9 \%$ \\
\hline & Fully Family Owned & 3 & 2 & 9 & 6 & 8 & 2 & 2 & $12 \%$ \\
\hline 7 Professional & $<2$ years & 3 & 0 & 5 & 4 & 3 & 5 & 4 & $9 \%$ \\
\hline \multirow[t]{4}{*}{ Experience } & $2-5$ years & 7 & 10 & 9 & 26 & 11 & 15 & 15 & $35 \%$ \\
\hline & $6-10$ years & 11 & 14 & 20 & 16 & 31 & 19 & 6 & $43 \%$ \\
\hline & $11-20$ Year & 4 & 7 & 2 & 2 & 10 & 4 & 3 & $12 \%$ \\
\hline & $\geq 20$ Year & 1 & 1 & 0 & 1 & 0 & 0 & 0 & $1 \%$ \\
\hline 8. Legal of & Enterprise Business & 10 & 15 & 15 & 20 & 16 & 13 & 12 & $38 \%$ \\
\hline \multirow[t]{3}{*}{ Business } & Commander (CV) & 11 & 11 & 13 & 23 & 23 & 16 & 12 & $41 \%$ \\
\hline & Limited Liability Company & 3 & 3 & 7 & 4 & 12 & 11 & 3 & $16 \%$ \\
\hline & Cooperative & 2 & 3 & 1 & 2 & 4 & 3 & 1 & $6 \%$ \\
\hline 12. Operation & $\leq 2$ Yeas & 3 & 2 & 2 & 1 & 3 & 2 & 3 & $9 \%$ \\
\hline \multirow[t]{2}{*}{ Duration } & 2 - 5 Years & 3 & 5 & 4 & 7 & 8 & 6 & 5 & $14 \%$ \\
\hline & $5-10$ Years & 7 & 10 & 11 & 16 & 16 & 13 & 6 & $29 \%$ \\
\hline
\end{tabular}




\begin{tabular}{|c|c|c|c|c|c|c|c|c|c|}
\hline & $>10$ Years & 13 & 15 & 19 & 25 & 28 & 22 & 14 & $51 \%$ \\
\hline 13. Number of & 5 - 19 people & 16 & 23 & 21 & 19 & 37 & 29 & 20 & $61 \%$ \\
\hline Employees & 20 - 99 people & 10 & 9 & 15 & 30 & 18 & 14 & 8 & $39 \%$ \\
\hline 14. Turnover of & $\leq 1$ Billion / Year & 14 & 15 & 20 & 32 & 34 & 24 & 16 & $58 \%$ \\
\hline Sales & $1-3$ Billion / Year & 12 & 17 & 16 & 17 & 21 & 19 & 12 & $42 \%$ \\
\hline 15. Company & $\leq 200$ Million & 9 & 11 & 9 & 11 & 16 & 13 & 8 & $29 \%$ \\
\hline Assets & 200 Million - 10 Billion & 17 & 21 & 27 & 38 & 39 & 30 & 20 & $71 \%$ \\
\hline \multicolumn{4}{|c|}{$\begin{array}{ll} & \text { Region 4: Mojokerto } \\
& \text { District } \\
\text { Districts } & \text { Region 5: Surabaya City } \\
\text { an District } & \text { Region 6: Sidoarjo } \\
\text { tto City } & \text { Districts } \\
\end{array}$} & \multicolumn{6}{|c|}{ Region 7: Lamongan Districts } \\
\hline
\end{tabular}

The results of collecting questionnaires to 284 elected leaders as respondents in this study, there were 15 questionnaires that did not provide complete answers, so they had to be discarded, while the total number of questionnaires answered in full was 269 and was the number of respondents further analyzed in this study.

To answer the hypothesis in this study used Structural Equation Modeling (SEM) which is an integrated approach between Factor Analysis, Structural Models, and Analysis Path. On the other hand, SEM it is also an integrated approach between data analysis and variable variables. Selected SEM in this study because researchers can carry out three activities simultaneously, namely examining validity and reliability of instruments, testing the relationship model between latent variables (equivalent to analysis path), and obtaining models that are useful for forecasting (equivalent to structural models or regression analysis).

\subsection{Operational definitions of variables}

Demographic operationalized as knowledge, experience, and skills of owners/leaders of small and medium enterprises (SMEs) represented as education, age, work experience, professional experience, and family background 13.

Information Technology is operationalized as a competency-based infrastructure 23 which is represented as the equipment used for business including the use of computers and telephone, as well as the number of computers and their use for business relations via email.

Survival is operationalized as the continuity of the company's business (Survival) 11 as measured by sales ability, increase in company assets, number of employees, type of product produced and length of business operations.

Of each dimension Demographics, Information and Survival is measured using indicators indicator as follows:

Table 3: Classification of Latent Variables and Research Indicators

\begin{tabular}{cl} 
Variable Latent & \multicolumn{1}{c}{ Indicators } \\
Exogenous unobserved & \multicolumn{1}{c}{ Exogenous observed } \\
Demographics $^{13}$ & dem1: Education \\
& dem2: Age \\
& dem3: Old work in companies \\
& dem4: Family background \\
& dem5: previous experience
\end{tabular}




\begin{tabular}{ll}
\hline Endogenous unobserved & \multicolumn{1}{c}{ Endogenous observed } \\
ICT & ti1: The number of computers \\
& ti2: The use of computers \\
& ti3: correspondence via Email \\
& ti4: Use the phone for business affairs \\
& sur1: Old Operating companies \\
& sur2: Corporate Asset \\
& sur3: Sales turnover \\
& sur4: type products \\
& sur5: Number of Workers \\
\hline
\end{tabular}

\section{Result}

From the evaluation of the criteria Goodness of fit Indices After modifying the variables (revised), the results of the SEM analysis are new Chi-Square, Probability, CMIN/DF, RMSEA, AGFI, GFI, TLI, and CFI have met the criteria, as well shown in Figure 1 below. Based on the evaluation of the criteria for Goodness of fit Indices Final Model SEM in Table 6 it is shown that the model for each criterion is stated to be very good.

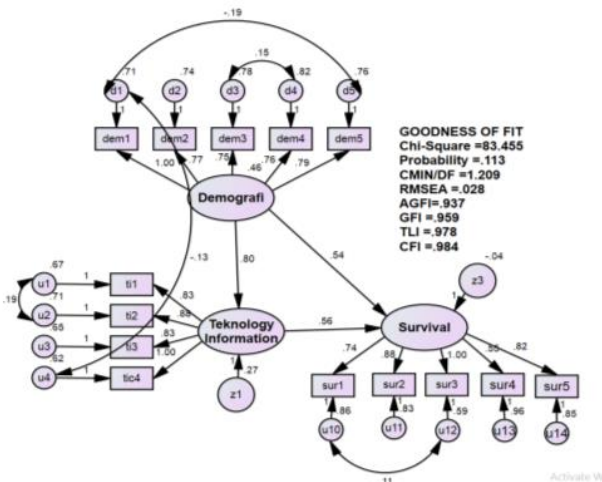

Fig. 1 Final Model SEM Analysis

To test the acceptance or rejection of the final SEM model using the test Goodness of Fit, Based on the evaluation of the Goodness of fit Indices Final Model SEM in Figure 1 shows that the model for each criterion is stated to be very good.

Based on the results of the analysis of the power of influence between variables both direct influence (Table 2), the following is presented the recapitulation of these influences, making it easier to test the hypothesis in this study.

Table 4: Recapitulation of the Results of Analysis of the Direct, Indirect, and Total Influences, Source: raw data processed in 2018

\begin{tabular}{llccc}
\hline No & Line & Direct & $\begin{array}{c}\text { Impact } \\
\text { Indirect }\end{array}$ & Total \\
\hline 1. & Demographic to Information Technology & .724 & - & - \\
2. & Demographic to Survival & .519 & - & - \\
3. & Information Technology to Survival & .604 & - & - \\
\hline
\end{tabular}




\begin{tabular}{llllc}
\hline 4. & $\begin{array}{l}\text { Demographics to Survival through } \\
\text { Information Technology }\end{array}$ & - & .437 & .956 \\
\hline
\end{tabular}

By knowing the direct, indirect and total influences as presented in Table 4 as well as the evaluation results of the Goodness of Fit Indices on the structural model, showing that the suitability test of this model results in a good level of acceptance. Therefore, it can be concluded that the hypothesis which states that the indicators are the underlying dimensions for the variables that exist for performance so that the "model" can be accepted or feasible to use to test the hypothesis in this study.

The hypothesis tested based on several coefficients of relations between dimensions in Table 4 above can be described as follows:

1. Demography has a strong, positive and significant direct effect on information technology of .724, and has a direct, strong, positive and significant influence on the survival of small businesses and medium (SMEs) amounting to .519 .

2. Information Technology has a strong, positive and significant influence on the performance of small and medium enterprises (SMEs) amounting to .604

3. Demography has indirect influence through information technology is very strong, positive and significant to the performance of small and medium enterprises (SMEs) of.956

\section{Discussion}

\subsection{Discussion of Results testing}

Human Capital seen from demographic dimensions directly has a strong influence on the survival of small and medium enterprises (SMEs) this in accordance with the results of research conducted by 22, 17, 24 which said the component components have a direct influence on performance, besides human capital also has a strong influence on information technology as found by $5,17,24$, on the other hand, human capital has a very strong indirect influence on the performance of small and medium enterprises (SMEs).

\subsection{Limitations}

a. This study was conducted with a static approach, which only looked at the possibilities of what resources small and medium enterprises (SMEs) have.

b. This study sees human capital only from demographic dimensions of owners/leaders, information technology, and business continuity for small and medium enterprises (SMEs).

\subsection{Theoretical Implications}

This conceptual model was developed as an attempt to analyze the influence of the ability of human resources owned by small and medium enterprises (SMEs), facilities and infrastructure to support human resource activities, to measure the survival of small and medium enterprises (SMEs). 
In general, this study succeeded in confirming the theories and results of previous studies on the influence of human capital from demographic dimensions on the survival of small and medium enterprises (SMEs). The structural analysis tested can prove the research path outlined in a model. Almost all the hypotheses tested can be verified. In particular, the results of this study can strengthen theories derived from the concepts of human capital, information technology, and survival and can be developed for future research by looking at other dimensions of dimensions for small and medium enterprises (SMEs).

\section{Acknowledgments}

The work related to this paper was carried out as part of a research project funded by RISTEKDIKTI entitled Engineering Lever Model Performance of Micro, Small and Medium Enterprises (MSMEs) as an Alternative Strategy to Increase Competitiveness and Sustainable Appeal Power; in accordance with the contract Number: 257 / NR-LPPM / 03 / V / 2018

\section{References}

[1] C. Higson, "Book review Intangibles: Management, Measurement, and Reporting by Baruch Lev, Washington, DC, Brookings Institution Press, 2001, pp. viii+216," Int. J. Account., vol. 36, no. 4, pp. 501-503, 2001.

[2] N. Lado, A. Maydeu-olivares, and J. Rivera, "Measuring market orientation in several populations A structural equations model," no. 1993, 1995.

[3] Teece, D. J. The Knowledge Economy and Intellectual Capital Management. in Managing Intellectual Capital 3-32 (OxfordUniversity Press, 2002). doi:10.1093/0198295421.003.0001

[4] Lonnqvist, A. \& Kujansivu, P. Designing and implementing an intellectual capital management system: applying the Meritum Guidelines in practice. Int. J. Knowl. Manag. Stud. 1, 276 (2007).

[5] Rimmel, G. The New Organizational Wealth: Managing and Measuring KnowledgeBased Assets, Karl Erik Sveiby, Berrett-Koehler, San Fransisco, 1997, 275 pp. Scand. J. Manag. 17, 522-524 (2001).

[6] Roos, G. \& Roos, J. Measuring your company\{\textquotesingle\}s intellectual performance. Long Range Plann. 30, 413-426 (1997).

[7] Mouritsen, J. \& Murthy, V. Strategic Performance Measures and Strategizing: Translations of Customer Orientation via the Service Profit Chain in a Bank. AOS, 2d resubmission (2012). doi:10.1093/aje/154.4.322

[8] Roos, G. Knowledge management, intellectual capital, structural holes, economic complexity and national prosperity. J. Intellect. Cap. 18, 745-770 (2017).

[9] Youndt, M. A. \& Snell, S. A. Intellectual Capital Measure. (2004). doi:10.1037/t68205-000

[10] Masupha, L. P., and Andrisha Beharry-Ramraj, Amolo, J. \& and. State financial assistance within Lesotho Maseru's small, medium and micro enterprises. Public Munic. Financ. 6, 7-14 (2017).

[11] Meyer, F. \& Kirsten, J. \{MODELLING $\}$ TTHE $\}$ \{WHEAT $\}$ \{SECTOR $\}$ IN $\}$ \{SOUTH\} \{AFRICA . Agrekon 44, 225-237 (2005).

[12] Mouritsen, J. \& Murthy, V. Strategic Performance Measures and Strategizing: Translations of Customer Orientation via the Service Profit Chain in a Bank. AOS, $2 d$ resubmission (2012). doi:10.1093/aje/154.4.322

[13] Ostgaard, T. A. \& Birley, S. New venture competitive strategies and their relation to growth. Entrep. Reg. Dev. (1995). doi:10.1080/08985629500000008 
[14] Rimmel, G. The New Organizational Wealth: Managing and Measuring KnowledgeBased Assets, Karl Erik Sveiby, Berrett-Koehler, San Fransisco, 1997, 275 pp. Scand. J. Manag. 17, 522-524 (2001).

[15] Rocha, V. \& Van Praag, M. C. The "Entrepreneurial Boss"; Effect on Employees' Future Entrepreneurship Choices: A Role Model Story? IZA Work. Pap. (2016).

[16] Roos, G. \& Roos, J. Measuring your company\{ \textquotesingle \}s intellectual performance. Long Range Plann. 30, 413-426 (1997).

[17] Roos, G. Knowledge management, intellectual capital, structural holes, economic complexity and national prosperity. J. Intellect. Cap. 18, 745-770 (2017).

[18] Teece, D. J. The Knowledge Economy and Intellectual Capital Management. in Managing Intellectual Capital 3-32 (Oxford University Press, 2002). doi:10.1093/0198295421.003.0001

[19] Youndt, M. A. \& Snell, S. A. Intellectual Capital Measure. (2004). doi:10.1037/t68205-000

[20] Gundlach, E. Human capital and economic development: A macroeconomic assessment. Intereconomics 32, 23-35 (1997).

[21] Becker, B. E., Huselid, M. A., Pickus, P. S. \& Spratt, M. F. $\{$ HR $\}$ as a source of shareholder value: Research and recommendations. Hum. Resour. Manage. 36, 39-47 (1997).

[22] Bruderl, J., Preisendorfer, P. \& Ziegler, R. Survival Chances of Newly Founded Business Organizations. Am. Sociol. Rev. 57, 227 (1992).

[23] Deng, H. \& Gupta, P. Critical Success Factors for Information Systems Implementation: An End-User Perspective. Proc. Inf. Resour. Manag. Assoc. Int. Conf. (2005). doi:10.4018/978-1-59140-822-2.ch019

[24] Clover, T. A. \& Darroch, M. A. G. \{OWNERS $\{\{$ textquotesingle $\{$ PERCEPTIONS $\} \quad\{\mathrm{OF}\} \quad\{$ FACTORS $\} \quad\{$ THAT $\} \quad\{$ CONSTRAIN $\}$ \{THE $\{$ SURVIVAL $\} \quad\{$ AND $\} \quad\{$ GROWTH $\} \quad\{\mathrm{OF}\} \quad\{$ SMALL,,$\{$ MEDIUM $\} \quad\{$ AND $\}$ $\{$ MICRO $\} \quad\{$ AGRIBUSINESSES $\} \quad\{$ IN $\} \quad\{$ KWAZULU $\}-\{$ NATAL $\}, \quad\{$ SOUTH $\}$ \{AFRICA\}. Agrekon 44, 238-263 (2005).

[25] Booyens, I. Are small, medium- and micro-sized enterprises engines of innovation? the reality in South Africa. Sci. Public Policy (2011). doi:10.3152/030234211X12834251302445

[26] Darroch, M. A. G. \& Mushayanyama, T. Smallholder farmers' perceptions of factors that constrain the competitiveness of a formal organic crop supply chain in \{KwaZulu\} Natal, South Africa. South African J. Econ. Manag. Sci. 9, 498-520 (2014).

[27] Ostgaard, T. A. \& Birley, S. New venture competitive strategies and their relation to growth. Entrep. Reg. Dev. (1995). doi:10.1080/08985629500000008

[28] Rocha, V. \& Van Praag, M. C. The "Entrepreneurial Boss"; Effect on Employees' Future Entrepreneurship Choices: A Role Model Story? IZA Work. Pap. (2016).

[29] Harada, N. Who succeeds as an entrepreneur? An analysis of the post-entry performance of new firms in Japan. Japan World Econ. 15, 211-222 (2003).

[30] Jovv-Llopis, E. \& Segarra-Blasco, A. What is the Role of Innovation Strategies? Evidence from Spanish Firms. \{SSRN\} Electron. J. (2016). doi:10.2139/ssrn.2845894

[31] Masupha, L. P., and Andrisha Beharry-Ramraj, Amolo, J. \& and. State financial assistance within Lesotho Maseru's small, medium and micro enterprises. Public Munic. Financ. 6, 7-14 (2017). 
[32] Carroll, G. R. \& Hannan, M. T. Density Dependence in the Evolution of Populations of Newspaper Organizations. Am. Sociol. Rev. 54, 524 (1989).

[33] Hair, J. F., Ringle, C. M. \& Sarstedt, M. Partial Least Squares Structural Equation Modeling: Rigorous Applications, Better Results and Higher Acceptance. Long Range Plann. (2013). doi:10.1016/j.lrp.2013.01.001 